\title{
BMJ Paediatrics Open \\ COVID-19 and the impact on child dental services in the UK
}

To cite: Okike I, Reid A, Woonsam K, et al. COVID-19 and the impact on child dental services in the UK. BMJ Paediatrics Open 2021;5:e000853. doi:10.1136/ bmjpo-2020-000853

Received 5 November 2020 Revised 21 December 2020 Accepted 6 January 2021

Check for updates

(c) Author(s) (or their employer(s)) 2021. Re-use permitted under CC BY-NC. No commercial re-use. See rights and permissions. Published by BMJ.

${ }^{1}$ Paediatrics, University Hospitals of Derby and Burton NHS Foundation Trust, Derby, UK ${ }^{2}$ Public Health Improvement Team, Public Health England, Midlands, Nottingham, UK ${ }^{3}$ Mill Hill Dental Clinic, Community Dental Services CIC, 2 Mill Hill Road Derby, UK ${ }^{4}$ Regional Postgraduate Dental Dean Midlands and East, Health Education England, Leicester, UK

Correspondence to Dr Ifeanyichukwu Okike; iokike@nhs.net
The SARS-CoV-2 (COVID-19) pandemic has posed significant challenges to the health, social, financial and educational systems globally. While COVID-19 produces very severe illness, and in some cases death, mainly in the elderly, children and young people have been somewhat protected. One per cent to three per cent of COVID-19 cases have been reported in children, ${ }^{12}$ with very few experiencing severe symptoms, and up to 15 June 2020 there have only been five known deaths in people aged $<16$ years in England and Wales. The predicted mortality risk for children is 1 in 5.3 million. $^{3}$

The UK, like other countries, instituted a lockdown in response. Much has been written about the consequence of lockdown on children's services, such as declining emergency attendances, ${ }^{4}$ delayed presentation and missed childhood immunisation. ${ }^{56}$ There are insidious consequences, such as disruption to schooling, especially within disadvantaged families, and the long-term impact will have individual and societal changes, as discussed in a recent BMJ opinion piece. ${ }^{6}$

However, little consideration has been given to oral health, an aspect of child health which is commonly overlooked but deserves to be prioritised due to its impact on general health. As a result of the national lockdown and scaling back on services in England, the Chief Dental Officer (CDO) advised on 25 March that all routine, non-urgent dental care should be stopped and deferred. ${ }^{7}$ Practices were advised to provide a virtual emergency assessment service, mainly using a telephone triage system, and only refer to urgent care hubs for essential clinical treatment.

As a result, children and young people in the UK, including a group of infants who would have been eligible for their first dental visit (365000, i.e., half of the birth cohort in the previous year), ${ }^{8}$ have been denied access to routine dental care. Even when services resumed in June, the capacity to see patients in National Health Service general dental practice was restricted. This is in part due to additional personal protective equipment and fallow time requirements, particularly for all aerosol-generating procedures. Many families remain understandably anxious about returning to perceived 'high-risk' environments for non-urgent assessments and treatment.

The interruption of routine care included the cancellation of elective tooth extraction for dental caries under general anaesthetic (GA). While caries is a largely preventable disease, it affects $23 \%$ of children aged 5 years in England and is a notable measure of health inequality. ${ }^{9}$ In a recent publication highlighting the indirect consequences of COVID-19, child oral health was conspicuously missing. ${ }^{5}$ This is despite oral health being highlighted in the Royal College of Paediatrics and Child Health's 2020 Child Health Report.

There is still no confirmed timeline for the full resumption of routine GA services for paediatric dentistry and only small numbers of children with the most severe symptoms are being prioritised. In England, over 43000 children are usually admitted to hospital due to dental caries each year ${ }^{10}$; denial of this treatment means the additional potential for these children to suffer with pain and infection. Some children will face being admitted through emergency departments for avoidable surgery as a result. The impact of dental caries on all aspects of life cannot be overemphasised.

Also in response to COVID-19, many health visitor and school nursing duties have been suspended, and in many parts of the UK these workers play a key role in providing oral health advice to vulnerable and high-risk families. The CDO also recommended that all community outreach activities such as oral health improvement programmes and dental surveys should be suspended. ${ }^{7}$

Through these community services and public health initiatives, including the Dental 
Check By One campaign, ${ }^{11}$ momentum was being gained in the fight against dental caries. The impact of COVID-19 on these services jeopardises progress. As healthcare providers, we must find alternative ways of reaching families and champion the needs of this vulnerable group of young people.

First, we should all be promoting and integrating child oral health in our professional practice by making every contact count, ${ }^{12}$ using the Mini Mouth Care Matters resources (https://mouthcarematters.hee.nhs.uk/ links-resources/mini-mcm-resources-2/) particularly for high-risk patients. This can be achieved by providing effective mouth care advice for inpatients, appropriate signposting to local dental services and using oral health resources. ${ }^{11} 13$.Local initiatives like websites summarising key oral health messages and practice (www.derbysmiles. info) could be helpful.We should also advocate for the inclusion of oral health within public health policy. The government has recently launched a national obesity strategy. ${ }^{14}$ Obesity and tooth decay are inextricably linked to excess sugar consumption ${ }^{9}$ and require a joined up management strategy. Recent Public Health England publication reported an association between children's weight and dental caries prevalence and severity, even when other potential influences such as deprivation were considered. Children who are underweight or overweight and very overweight were more likely to have experienced dental caries than those of a healthy weight. However, when adjusted for deprivation, ethnicity and water fluoridation status, the likelihood of having dental caries was significantly higher only for those children who are overweight and very overweight (https://assets.publishing. service.gov.uk/government/uploads/system/uploads/attachment_data/file/844121/BMI_dental_caries.pdf).

The above findings emphasise the importance of addressing the social determinants of health to reduce oral health inequities while also tackling specific factors such as unhealthy diets through a proportionate universalism approach. COVID-19 has exposed societal inequality, which will continue to impact without immediate action. The incidence of tooth decay is doubled in deprived communities ${ }^{9}$ and is impossible to address without tackling social inequality.

Continuous support for water fluoridation is essential. It is a safe, cost effective, public health intervention with proven reduction in the incidence of caries, ${ }^{12}$ as well as specifically reducing socioeconomic status inequalities in dental health. ${ }^{1516}$ Unfortunately, only $14 \%$ of the UK water supply is fluoridated. ${ }^{17}$

In a recent systematic review, Firmino et al concluded that low parental oral health literacy was associated with dental caries among their children. ${ }^{18}$ There is therefore a great need for a national initiative to drive oral health literacy with parents and carers as the causes of caries are multifactorial. University College London Institute of Health Equity published a document on local action for improving health literacy to reduce health inequalities in 2015 (http:// www.instituteofhealthequity.org/resources-reports / local-action-on-health-inequalities-health-literacy-toreduce-health-inequalities / health-literacy-improvinghealth-literacy-to-reduce-health-inequalities-briefing. pdf). This approach, when complemented with the work previously done at schools and nurseries, could be effective. We recommend the resurrection of the schoolsupervised toothbrushing now that children are going back to school. This will help establish and consolidate mouthcare regimes.

As we prepare for an anticipated further COVID-19 waves, these are issues that must be discussed openly. Otherwise, we will come out of the other side of COVID-19 and find out that immunisation, education, cancer and diabetes are addressed but children will have experienced disruption to their schooling, diet and sleep purely because we refused to consider the prevention and management of their neglected dental health.

In conclusion, we recommend that rather than the current default position of delegating the responsibility to dental professionals alone, that all healthcare workers (paediatricians and general practitioners, nurses, midwives and health visitors), parents, schools and other institutions should work collaboratively to tackle child oral health. The cost to the NHS for preventing tooth decay is minimal compared with the cost of extractions under GA (£36 million per year). ${ }^{19}$ Tackling child oral health nationally and indeed globally needs a very simple health message, willingness to act and not simply implied actions.

Twitter Ifeanyichukwu 0kike @worldzico, Katherine Woonsam @katiewoonsam and Andrew Dickenson @HEEMDentalDean

Contributors 10 conceived the idea and wrote the first draft. All authors contributed to the writing and editing, and approved the final draft for submission.

Funding The authors have not declared a specific grant for this research from any funding agency in the public, commercial or not-for-profit sectors.

Competing interests None declared.

Patient and public involvement Patients and/or the public were not involved in the design, or conduct, or reporting, or dissemination plans of this research.

Patient consent for publication Not required.

Provenance and peer review Commissioned; externally peer reviewed.

Open access This is an open access article distributed in accordance with the Creative Commons Attribution Non Commercial (CC BY-NC 4.0) license, which permits others to distribute, remix, adapt, build upon this work non-commercially, and license their derivative works on different terms, provided the original work is properly cited, appropriate credit is given, any changes made indicated, and the use is non-commercial. See: http://creativecommons.org/licenses/by-nc/4.0/.

\section{ORCID iD}

Ifeanyichukwu Okike http://orcid.org/0000-0002-4001-2642

\section{REFERENCES}

1 Wu Z, McGoogan JM. Characteristics of and Important Lessons From the Coronavirus Disease 2019 (COVID-19) Outbreak in China: Summary of a Report of 72314 Cases From the Chinese Center for Disease Control and Prevention. JAMA 2020;323:1239-42.

2 Bialek S, Gierke R, Hughes M, et al. Coronavirus disease 2019 in children - United States, February 12-April 2, 2020. MMWR Morb Mortal Wkly Rep 2020;69:422-6. 
3 Healthcare Quality Improvement Partnership. PICANet report on COVID-19 confirmed cases admitted to paediatric intensive care, 2020. Available: https://www.picanet.org.uk/wp-content/uploads/ sites/25/2020/06/PICANet_COVID report_2020-06-23 v1.3.pdf [Accessed 13 Aug 2020].

4 Isba R, Edge R, Jenner R, et al. Where have all the children gone? Decreases in paediatric emergency department attendances at the start of the COVID-19 pandemic of 2020. Arch Dis Child 2020;105:704.

5 Lynn RM, Avis JL, Lenton S, et al. Delayed access to care and late presentations in children during the COVID-19 pandemic: a snapshot survey of 4075 paediatricians in the UK and Ireland. Arch Dis Child 2020. doi:10.1136/archdischild-2020-319848. [Epub ahead of print: 25 Jun 2020].

6 Ladhani S, Viner RM, Lynn RM. Lockdown measures reduced the risk of covid-19, but had unintended consequences for children. BMJ opinion, 2020. Available: https://blogs.bmj.com/bmj/2020/ 08/06/lockdown-measures-reduced-the-risk-of-covid-19-but-hadunintended-consequences-for-children/ [Accessed 13 Aug 2020].

7 NHS England. Issue 3, Preparedness letter for primary dental care - 25 March 2020, 2020. Available: https://www.england.nhs. uk/coronavirus/publication/preparedness-letters-for-dental-care/ [Accessed 13 Aug 2020].

8 Office for National Statistics. Births in England and Wales, 2019. Available: https://www.ons.gov.uk/peoplepopulationandcommunity/ birthsdeathsandmarriages/livebirths/bulletins/birthsummarytablesen glandandwales/2019 [Accessed 13 Aug 2020]

9 Public Health England. Child oral health: applying all our health, 2019. Available: https://www.gov.uk/government/publications/childoral-health-applying-all-our-health/child-oral-health-applying-all-ourhealth [Accessed 13 Aug 2020].

10 The Royal College of Surgeons of England. Hospital admissions for 5-9 year olds with tooth decay more than double those for tonsillitis,
2019. Available: https://www.rcseng.ac.uk/news-and-events/mediacentre/press-releases/dental-decay-hosp-admissions/ [Accessed 13 Aug 2020].

11 Resources. British Society of paediatric dentistry, 2020. Available: https://www.bspd.co.uk/Professionals/Resources [Accessed 13 Aug 2020].

12 Godson J, Csikar J, White S. Oral health of children in England: a call to action! Arch Dis Child 2018;103:5-10.

13 Kidsvids. British Society of paediatric dentistry, 2020. Available: https://www.bspd.co.uk/kidsvids [Accessed 13 Aug 2020].

14 Department of Health and Social Care. New obesity strategy unveiled as country urged to lose weight to beat coronavirus (COVID-19) and protect the NHS, 2020. Available: https://www.gov. uk/government/news/new-obesity-strategy-unveiled-as-countryurged-to-lose-weight-to-beat-coronavirus-covid-19-and-protectthe-nhs [Accessed 13 Aug 2020].

15 Riley JC, Lennon MA, Ellwood RP. The effect of water fluoridation and social inequalities on dental caries in 5-year-old children. Int $J$ Epidemiol 1999;28:300-5.

16 Broadbent JM, Thomson WM. The effect of community water fluoridation on social inequalities in dental caries. Int $J$ Epidemiol 2015;44:i31.

17 Mullen J, European Association for Paediatric Dentistry. History of water fluoridation. Br Dent J 2005;199:1-4.

18 Firmino RT, Ferreira FM, Martins CC, et al. Is parental oral health literacy a predictor of children's oral health outcomes? Systematic review of the literature. Int J Paediatr Dent 2018;28:459-71.

19 Sky News. Tooth extraction 'epidemic' costs NHS millions, 2018. Available: https://news.sky.com/story/tooth-extraction-epidemiccosts-nhs-millions-11205389 [Accessed 13 Aug 2020]. 